UDC 504.054+628.161

DOI: https://doi.org/10.20535/2218-93002522019188264

\title{
POLYPROPYLENE MULTILAYER MELT-BLOWN CARTRIDGE: THE UNIVERSAL PARTICLES REMOVER FOR LIQUIDS FILTRATION
}

\author{
V.L. Ponomarev, S.L. Vasilyuk \\ LLC SPC Ecosoft \\ vponomarev@ecosoft.com
}

In this paper special emphasis is making on the so-called mechanical filter elements made of polypropylene obtained by melt-blown (MB) technology. Presented information about production and testing multilayer polypropylene filtering cartridges, and their properties comparison with monolayer analogues.

Key words: filtering cartridges, melt-blown technology, polypropylene, multilayer, tap water

Article history:

Received: 25 September 2019

Accepted: 5 November 2019

Print: 20 December 2019

These products are commonly used in water treatment starting from simple sedimentary in-line filter at the entrance to the apartment for removal of sharp chipped pipes, brown suspension of rust, crispy sand at the bottom of a bath and sticky sediment clay, ending reverse osmosis systems kitting. New experimental results allowed to take a fresh look at technology, structure and properties of MB cartridges [Ponomarev, 2015, Sikorska 2017, 2018].

Taking in to account the international market conditions with a certain notion about the traditional monolayer and innovative multilayer cartridges, we assigned the task to create a «fashionable» product - a depth cartridge containing two successive filter layers in the structure of one cylindrical body with different degrees tortuosity of the pore space corresponding to a micron rating (from outside to inside) of 20 and 5 microns (Fig. 1; layers 3 and 2). An internal strength layer (1) was provided in new product, which counteracts the forces of «squeezing», when it is contaminated, and an excessive pressure drop forms on it.

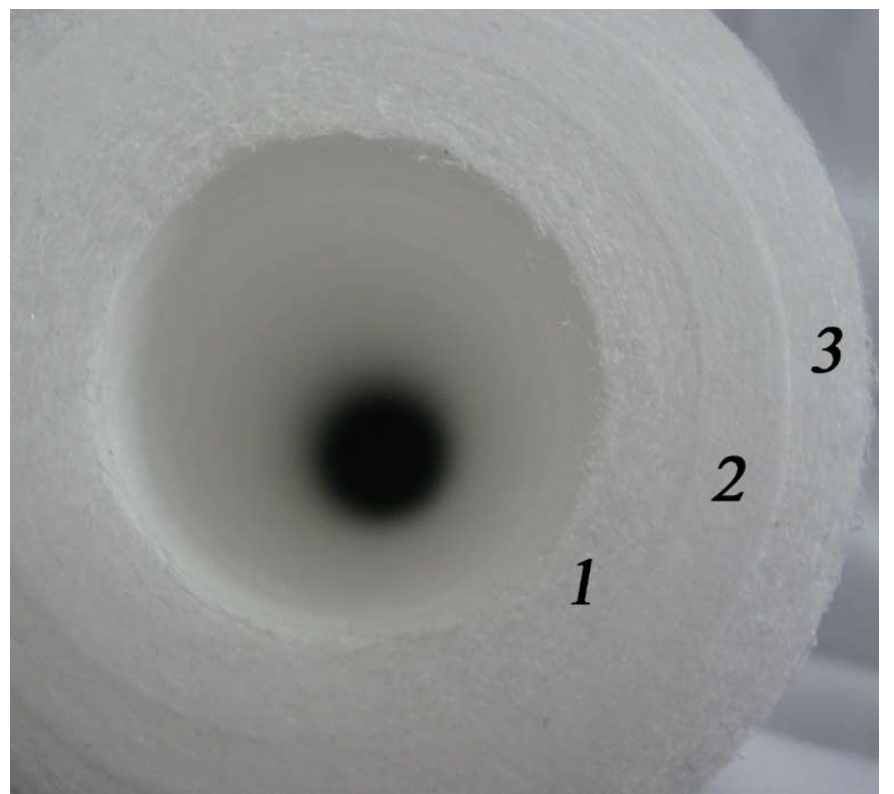

Fig.1. Cross section of a 2,5x10" $20 / 5 \mu \mathrm{m}$ multilayer cartridge. 1-supporting layer, 2-layer $5 \mu \mathrm{m}, 3$ layer $20 \mu \mathrm{m}$. 
Such kind of depth polypropylene cartridges for liquids filtration are called gradient or multilayers and can contain up to 3 or more layers along the cylinder section, working on the principle of «funnel» tapering from the periphery to the center. In the outer layers of the «funnel», due to mechanical retention, electrical and intermolecular interaction, larger impurities are placed, coalesce, adsorbed on the walls of the pores and retain the newly incoming particles. Direct detention mechanism smoothly goes into the mechanism of mechanical screening, increasing the efficiency of the process. Fine particles going through the «screening» layer further into the body of the cartridge, settle in the second layer, which is different from the outer more thinner microfibers and their packing density. The main thing is that officially declared characteristics of the «funnel» must corresponded with the size of particles have trapped. It is important that the level of efficiency must be at least $85 \%$, that according to WQA (Water Quality Association) rules corresponds to the rating of nominal filtration efficiency. Filtering cartridges holding up to $99.99 \%$ of particles, passes from the nominal to higher rating - the rating of absolute efficiency.

Advertising line of MB elements offered by various companies are almost identical. The product labeling looks in the following way: 1, 5, 10, 15, 25, 50 microns. But the problem is that firms do not give clients any instructions for each micron rating application. That raise the difficulties and incorrect using of cartridges. Our experience with drinking water, coming from Ukrainian water mains, after years of experiments allows to confidently say that for its high-quality treating against mechanical pollutions it is necessary to cover the contamination range from 5 microns and higher. That is why we choose the rating interval of 5-20 microns when creating a depth multilayer cartridge. Microbial area below 5 microns overlap by others water treating technologies (for example, ultrafiltration and reverse osmosis). Particles larger than 20 microns particularly not harmful for 20micron pores.

The various shapes of multilayer MB cartridges are presented on the World market no less than 25 years. They are characterized by more stable operation (resistance to water flow increases gradually), service life no less than 30\% compared with monolayer, low pressure drops, which contributes to more efficient filtering [Graver Technologies, 2019, SUEZ Water Technologies \& Solutions, 2019, Hangzhou Darlly Filtration Equipment Co.,Ltd, 2019]. If buyer, for example, deciding to install in-line filter at the entrance to the apartment, he saves place and money, because instead of two cartridges ( 20 and 5micron), in two separate filter holders, uses only one for 20/5 microns.

Few words about the theoretical approach to the technology of manufacturing a multilayers cartridge. The classical school of scientists developing fine-fiber filter materials previously headed by academician of the USSR I.V. Petryanov-Sokolov, identifies three main factors affecting the efficiency of above-mentioned materials: the diameter of the fibers in the layer, their density of packing and electric charge. Materials called FP (Petryanov filters) was producing in the USSR since 1936 and are still being produced in Russia to hold radioactive aerosols in the workshops of nuclear power plants, for gas masks and well-known respirator «Petal». Time has confirmed the selection of performance criteria fine fiber filters [Петрянов и др., 1968, Кирш и др., 2008].

The manufacturing process of melt-blown materials differs from the FP technology, but they have one principle - obtaining ultrathin polymer fibers in the form of a ready-to-use product. In our case, the melt-blown technology consists in obtaining a polypropylene melt in extruder, forcing it under the pressure through three consecutive dies with a total number of holes 1440, blowing out «melt streams» coming out of the holes with hot air and winding the «flow» of solidifying fibers onto a continuously rotating helical metal core. The resulting continuous pipe, with outside diameter of 62 or $116 \mathrm{~mm}$, is gradually «twisted» from the screw. At the same time, pipes are automatically cut off from it (taking into account subsequent shrinkage) of the required length.

It is impossible to create a multilayer cartridge without understanding the key parameters of process. Numerous literature describing the melt-blown process, as applied to nano- and microfiber canvases, identifies five fundamental factors of technology control [Bo, 2012, Lee, 1992, Ellison et al., 2007, Dutton, 2008]: viscoelastic properties of a polymer, extruder output, pressure of melt flow, 
temperature of inflation air, the diameter of the forming holes, the distance from the exit zone of the extrudate to the receiving winding. By varying the process parameters and analyzing the structure of the layers, as well as the properties of the resulting cartridges, we were able to implement a stable process.

Looking on the potential application of multilayers cartridges for water purification with a high concentration of suspended solids and mucus, the samples were tested using special instruments and methods. The hydrodynamic indicators in the range of water flow rate $0-1000 \mathrm{l} / \mathrm{h}$ were studied. For this purpose, has been applied stand (Fig. 2), based on standards [British standard 1997, 2005, GOST, 1993 ] and cartridges with the length 10 " and weight $100 \pm 2 \mathrm{~g}$.

Fig. 2. Stand for cartridges testing.

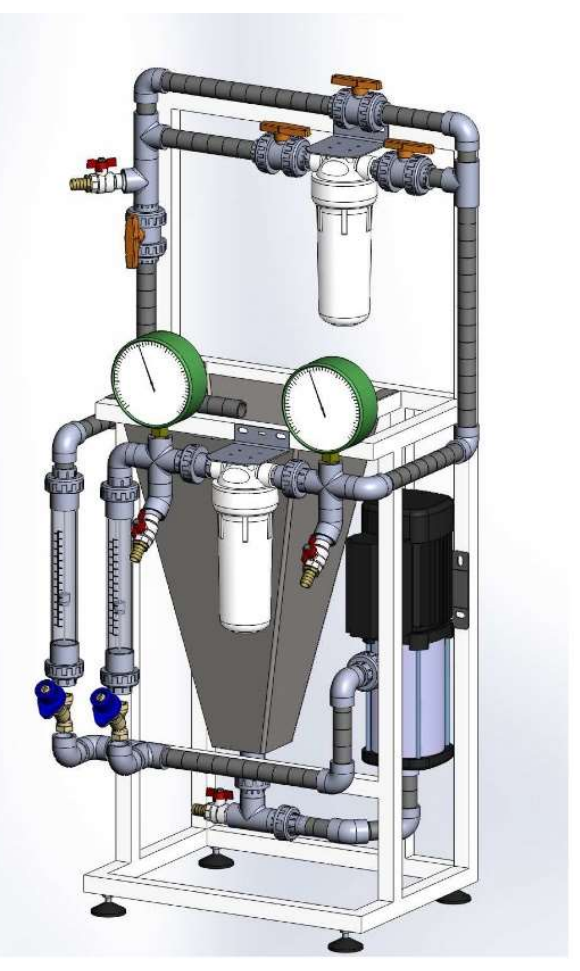

The initial pressure differential at the beginning of their operation is characterizes the potential behavior of the cartridges in the pollution process. It is clear that more dense bed (with a large initial pressure drop) have a shorter service life under the same conditions than less dense ones.

Five-micron monolayer analogues of well-known companies presented in Ukraine were tested (Table 1) for comparison. The results follow that the multilayer samples causes less of pressure differential than monolayers at the beginning of operation.

Table 1. The comparative assessment of initial pressure differential of multilayer and monolayer cartridges

\begin{tabular}{|l|c|c|c|c|c|}
\hline \multicolumn{1}{|c|}{ Marking } & Type & Mass, $g$ & Rating, $\mu \mathrm{m}$ & $\begin{array}{c}\text { Flow rate, } \\
1 / \mathrm{h}\end{array}$ & $\begin{array}{c}\text { Initial pressure } \\
\text { differential, bar }\end{array}$ \\
\hline Ecosoft 20/5 & multylayer & 100 & $20-5$ & 1000 & 0.02 \\
\hline AquaFilter FCPS5 & monolayer & 108 & 5 & 1000 & 0.2 \\
\hline AquaTOP Melavo & monolayer & 100 & 5 & 1000 & 0.08 \\
\hline H2O System B-PS & monolayer & 118 & 5 & 1000 & 0.06 \\
\hline
\end{tabular}

Based on the modern points of view, the optimal microstructure of the «ideal cartridge» should provide a low initial hydrodynamic resistance, high particle retention efficiency (of its rating and higher) and maximum service life without decreasing of efficiency. But the low hydrodynamic resistance (head loss) is not sufficient for complete estimation quality of the new product. 
As it was showing before, the effectiveness of the normal filter element should be at least $85 \%$. Given the multilayer structure of the element it was interesting to evaluate the capabilities of each layers. To exclude the mechanisms of mutual influence of dissimilar particles, testing was carried out using suspensions differing in particle size distribution (Fig. 3). The yellow curve of the differential distribution «coarse composition» of particles in the range of $\geq 10 \mu \mathrm{m}$ was obtained using a laser diffraction analyzer «Analysette 22» company Frisch, (Germany). The marker was prepared in laboratory conditions by repeatedly grinding a portion of quartz sand with intermediate elutriation and drying. The second orange curve represents a «fine» particle distribution of A2 grade Arizona desert sand particles in the range of 2-10 $\mu \mathrm{m}$ according to ISO12103-1, obtained using a Coulter Multisizer IIe TM particle counter from Coulter International Corporation (USA).

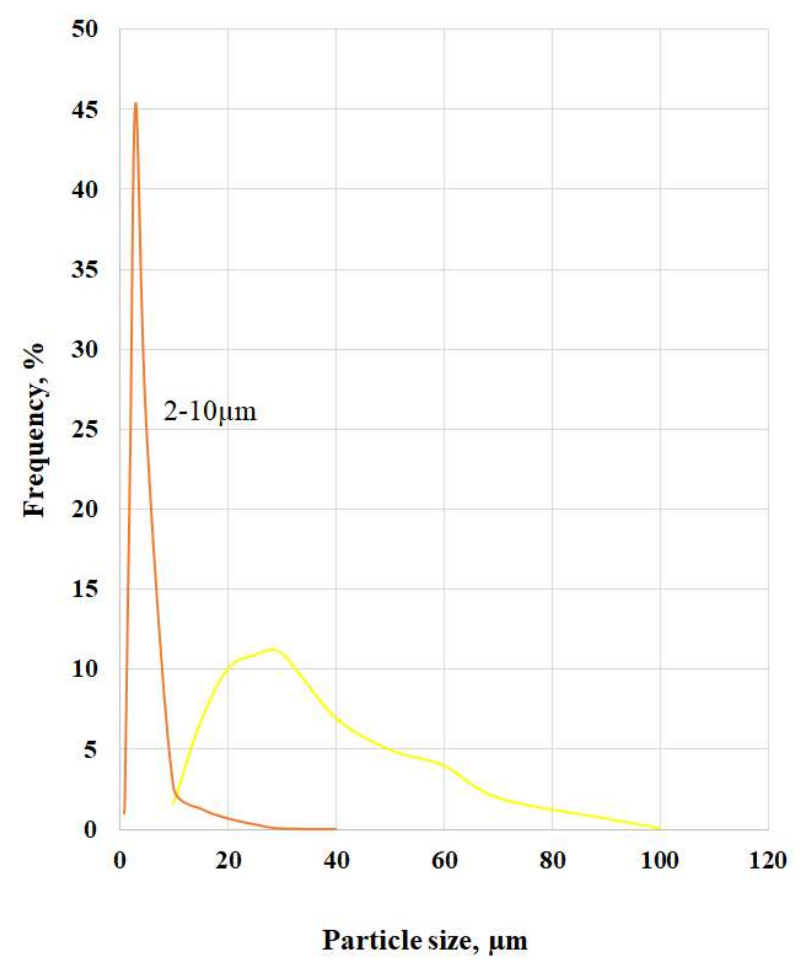

Fig. 3. Curves of the differential distribution of marker particles in size.

Based on the composition containing particles with a size of $\geq 10 \mu \mathrm{m}$ in the tank capacity (Fig. 2), a suspension with a concentration of suspended solids of $130 \mathrm{mg} / \mathrm{dm}^{3}$ was prepared, which was continuously mixed during the filtration process. Samples of filtered water were analyzed on a UV 2150 spectrophotometer from UNICO (USA) according to residual turbidity as indicated in GOST R50554-93 and the dropout coefficient according to GOST 10577 was calculated by the formula:

$$
\varphi=\left(1-\frac{\mathrm{x}_{2}}{\mathrm{X}_{1}}\right) * 100 \%,
$$

where X1 and X2 are the concentrations of mentioned above pollutant in the water samples taken before and after the cartridge. Dropout coefficient for the multilayer cartridges tested by particles $\geq 10$ $\mu \mathrm{m}$ was $99.3 \%$ under the water flow rate $1000 \mathrm{l} / \mathrm{h}$, inlet and outlet turbidity correspondingly 130 and $0.49 \mathrm{mg} / \mathrm{l}$. Dropout coefficient for the monolayer samples listed above also exceeded $99 \%$. The output filtrate turbidity after all sample was lower than the norm for turbidity $\leq 1 \mathrm{NOK}(1 \mathrm{NOK}=0.58 \mathrm{mg} /$ 1) accepted in European regulations.

Thus, comparing the developed multilayer cartridges with monolayer 5-micron analogues of other companies in terms of hydrodynamic resistance and particle dropout coefficient $\geq 10 \mu \mathrm{m}$, we got the lowest $(0.02$ bar at $1000 \mathrm{l} / \mathrm{h})$ loss of head at a nearly equal dropout coefficient. This result 
shows that for particles $\geq 10 \mu \mathrm{m}$ multilayer cartridge with filtering rating $20 / 5 \mu \mathrm{m}$ approaches to the absolute efficiency.

The properties of the 5-micron layer of the multilayer cartridges were investigated using standard marker Arizona desert sand (A2 ISO 12103-1). Testing was carried out according to the methods [British standard 1997, 2005, GOST, 1993] in the laboratory of Clack Corporation (USA). The particle size distribution in the inlet water and in filtrate was also determined on a Coulter Multisizer IIe TM particle size analyzer. The results are presented in fig. 4 and fig. 5. From fig. 4 it can be seen that in the range of particle sizes of $2-10 \mu \mathrm{m}$, the multilayer cartridge is distinguished by a reliable 5 micron layer, passing from 4000 particles with size $\geq 5 \mu \mathrm{m}$, only 560 , which correspond to $86 \%$. Consequently, it fully fits with the criteria of the WQA rating. Efficiency data (Fig. 5) show that in the range $<5 \mu \mathrm{m}$ it also holds impurities well, for example, $67.7 \%$ of particles $3 \mu \mathrm{m}$ (up to 7248 after 2338 pcs.) and $57.0 \%$ of particles $2 \mu \mathrm{m}$ (up to 3732 after 1603 pcs.).

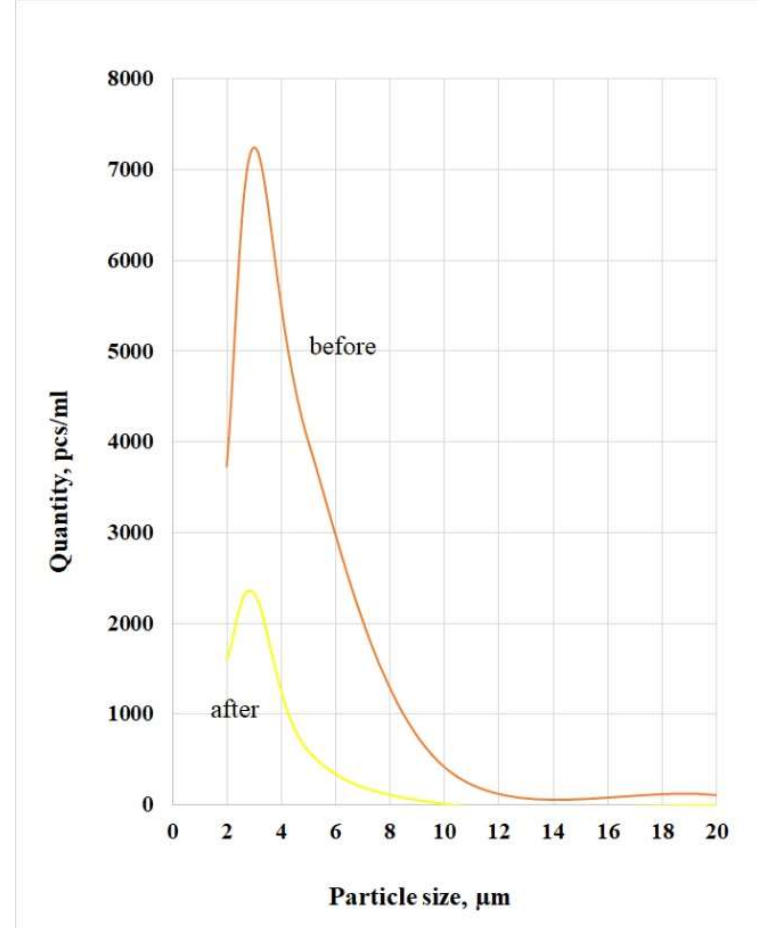

Fig. 4. The results of testing $2.5 \times 10$ " multilayers cartridges $20 / 5$ microns by marker particles $2-10$ micron.

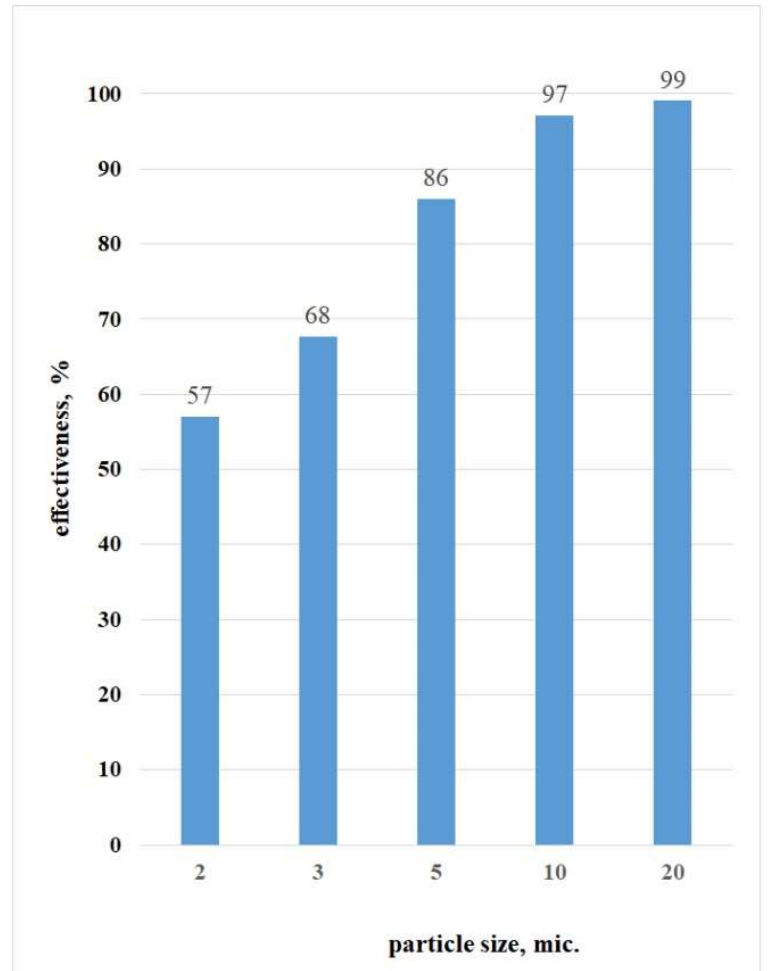

Fig. 5. The results of testing $2.5 \times 10$ " multilayers cartridges $20 / 5$ microns by marker particles $2-10$ micron.

Testing of the monolayer analogues AquaFilter FCPS5, AquaTOP Mellavo, H2O System B-PS according to the methods [British standard 1997, 2005, GOST, 1993] showed that they also meet all WQA conditions for filtering particles size $\geq 5 \mu \mathrm{m}$. To compare the resource capabilities $20 / 5 \mu \mathrm{m}$ multilayer cartridge and its monolayer analogues in real conditions, a special stand was developed in which tap water was simultaneously filtered through several samples installed in parallel. The flow rate adjustment on each line was provided with rotameters with flow control, the volume of filtered water summarized by the counters. The pressure differential on each filter holder was controlled with a head gauge. On each line, a flow rate of $240 \mathrm{l} / \mathrm{h}$ was installed, which was kept at a constant level throughout the experiment. Filtration was continued until a pressure differential of 1 bar, recommended by most manufacturers of MB elements, as a cartridge replacement criterion (Fig. 6). 


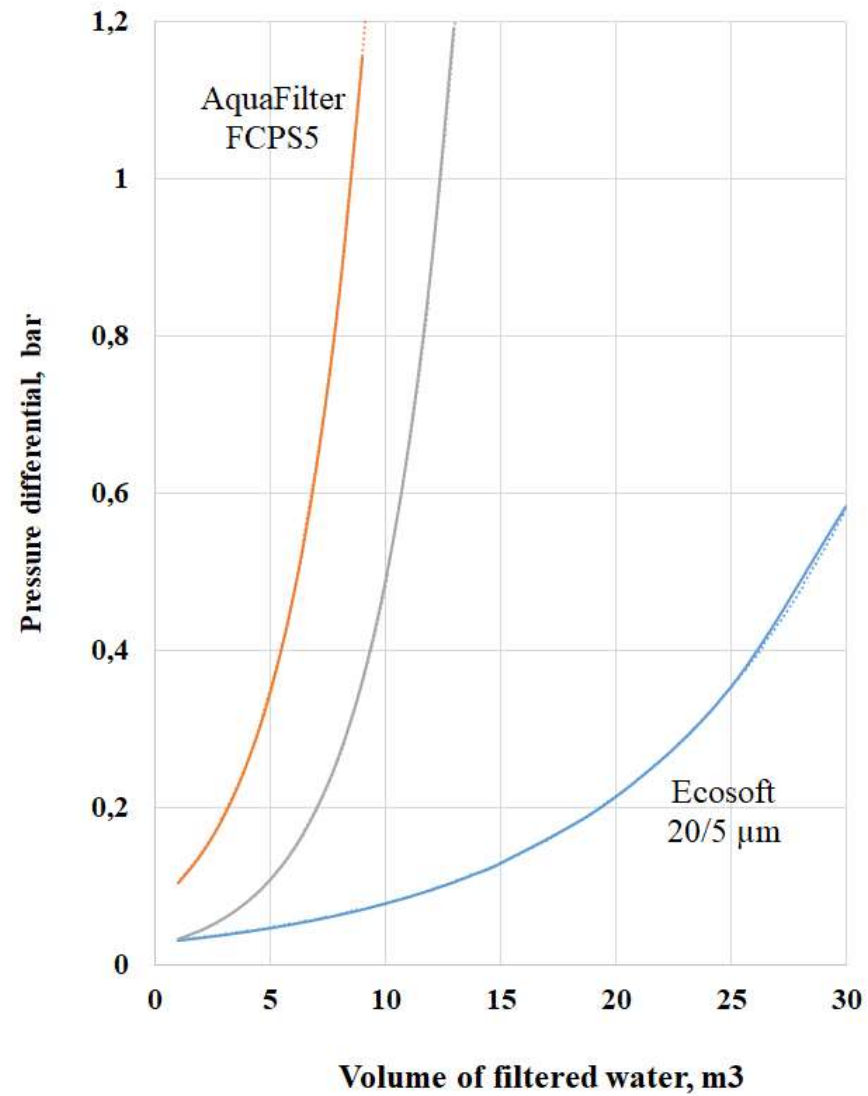

Fig.6. The valuation of different cartridges resources on reaching the differential pressure $1 \mathrm{bar}$.

Photos the cross sections of tested samples, shown in fig. 7, allows to understand the reason of such differences. On the cross-section of cartridge 20/5 microns (1) it is clearly visible brown color of $20 \mu \mathrm{m}$ layer, constituent $30 \%$ of the element working thickness (Fig. 1). Following him $5 \mu \mathrm{m}$ layer (also $30 \%$ of the thickness) has a yellow tint shade, confirming that the bulk contamination has already been removed by the previous layer, and it only residual concentration. The 3-rd support layer are not painted by impurities.

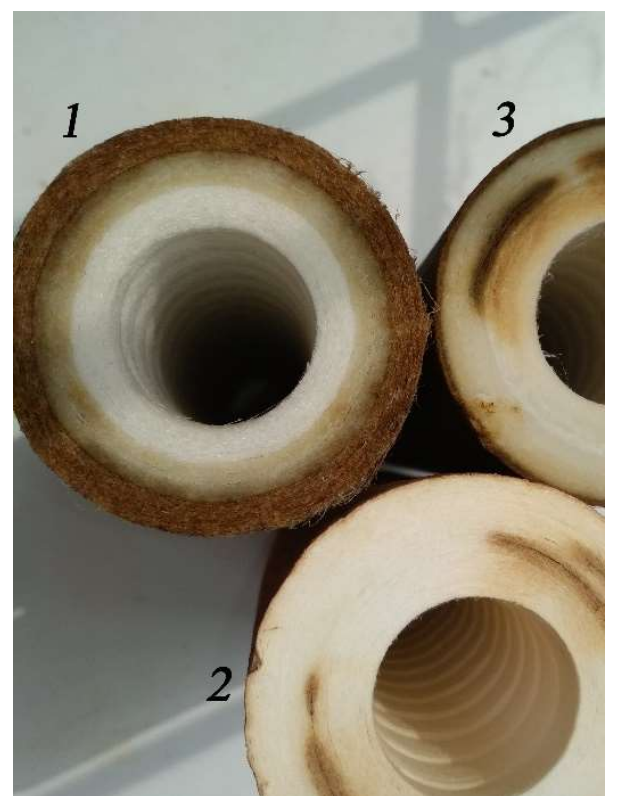

Fig. 7. The photographs of cross-sections of cartridges samples after filtering tap water. 1 - gradient 20/5 $\mu \mathrm{m}, 2$ - AquaFilter FCPS5, 3 - AquaTOP Mellavo. 
The opposite picture is observed on cross sections of monolayer cartridges $(2,3)$, where the contamination is laid exclusively on the surface, compacting under pressure and blockade the entire porous volume of the cylinder from further filtering process. There is no doubt the fact of the high efficiency tested 5 micron monolayer cartridges, but on the other hand, the question arises of the appropriateness of their use for treatment of complicated tap water due to the inconvenience associated with constant replacement, because the resource is $8-12 \mathrm{~m}^{3}$ cold water is the average monthly volume for a small family.

Summarizing the results of the work done, we can state the fact that a new high-quality product appeared on the Ukrainian market - a 20/5 micron multilayer cartridge, obtained by experts of Ecosoft using melt-blown technology with full scientific support and a description of the tactical and technical properties. Its serial production and use in domestic and industrial water treatment will bring significant economic benefits to consumers and will make it possible to abandon less effective counterparts in industries such as pharmaceuticals, electronics, beverages, chemical solutions, underground and waste water.

\title{
ГРАДИЕНТНЫЕ МЕLТ-ВLОWN КАРТРИДЖИ ИЗ ПОЛИПРОПИЛЕНА: УНИВЕРСАЛЬНОЕ УДАЛЕНИЕ ЧАСТИЦ ПРИ ФИЛЬТРАЦИИ ЖИДКОСТЕЙ
}

\author{
В.Л. Пономарев, С.Л. Василюк \\ ООО «НПО «Экософт»
}

В этой статье особое внимание уделяется так называемым механическим фильтруюшим элементам из полипропилена, полученным по технологии melt-blown (MB). Представлена информаџия о производстве и испытаниях многослойных полипропиленовых фильтрующих картриджей, а также сравнение их свойств с однослойными аналогами.

Ключевые слова: фильтрующие картриджи, технология melt-blown, полипропилен, многослойный, водопроводная вода.

\section{ГРАДІЄНТНІ МЕLТ-ВLОWN КАРТРИДЖІ 3 ПОЛІПРОПІЛЕНУ: УНІВЕРСАЛЬНЕ ВИДАЛЕННЯ ЧАСТИНОК ПРИ ФІЛЬТРАЩЇ̈ РІДИНИ}

\author{
В.Л. Пономарьов, С.Л. Василюк \\ vponomarev@ecosoft.com
}

У иүій статті особлива увага приділяється так званим механічним фільтруючим елементам з поліпропілену, отриманим за технологією melt-blown (MB). Вироби, про які йде мова, використовуються в водопідготовиі скрізь. Дані останніх років дозволяють по-новому подивитися на технологію отримання, структуру і властивості МВ картриджів. У статті розглядається фільтруючий елемент глибинної дї, щзо містить в структурі одного цииліндричного тіла два послідовно розташованих фільтруючих шару, з різним ступенем звивистості порового простору. Подібного роду поліпропіленові картриджі об'ємної дії для очищення рідин в літературі називаються багатошаровими і можуть містити по перетину цุиліндра до 3-х і більще шарів, щчо працюють за принщипом «воронки», щуо звужується від периферії до иентру.

Досвід роботи з питною водою, яка надходить з українських водопровідних магістралей, дозволяє впевнено сказати, щзо для ї̈ якісної механічної очистки необхідно перекрити діапазон забруднень від 5 мікрон і вище. Саме тому ми вибрали інтервал 5-20 мікрон при створенні експериментального виробу.

Можна стверджувати, щуо на ринку України з'явився новий якіснй вироб, як багатошаровий картридж 20/5 мкм, отриманий фахівиями ТОВ «НВО «Екософт» за технологією теlt-blown з повним науковим супроводом $і$ описом тактико-технічних властивостей. Його серійне 
виробництво $і$ використання у побутовій $і$ промисловій водопідготовці принесе значний економічний ефект споживачам в таких галузях, як фармацевтика, електроніка, напої, хімічні розчини, підземні і стічні води, продукти переробки нафти і газу.

Представлена інформація про виробництво і випробуваннях багатошарових поліпропіленових фільтруючих картриджів, а також порівняння їх властивостей з одношаровими аналогами. Ключові слова: фільтруючі картриджі, технологія теlt-blown, поліпропілен, багатошаровий, водопровідна вода.

\section{References}

Bo Z. Production of polypropylene melt blown nonwoven fabrics: Part II -Effect of process parameters Indian Journal of Fibre and Textile Research. 2012. 37 (4), 326-330.

Dutton K.C. Overview and analysis of the meltblown process and parameters. J. Text. Apparel, Technol. Manage. 2009. 6 (1), 1-25.

Ellison C. J., Phatak A., Giles D. W.. Macosko C. W., Bates F. S. Melt blown nanofibers: Fiber diameter distributions and onset of fiber breakup. Polymer. 2007. 48 (11), 3306-3316. doi: 10.1016/j.polymer.2007.04.005

Graver Technologies. www.gravertech.com. 2019.

Hangzhou Darlly Filtration Equipment Co.,Ltd. http://www.darllyfiltration.com/en/. 2019.

Kirsh A. A., Budyka A. K., Kirsh V. A. Filtration of aerosols with fiber materials FP. Russian Journal of General Chemistry. 2009. 79 (9), 2045-2050.

Lee Y., Wadsworth L. C. Effects of melt-blowing process conditions on morphological and mechanical properties of polypropylene webs. Polymer. 1992. 33 (6), 1200-1209. doi: 10.1016/00323861(92)90764-N

Petrânov I. V., Kozlov V. I., Basanov P. I., Ogorodnikov B. I. Voloknistye fil'truûsie materialy FP. Moscow: Khimiya, 1968. [In Russian].

Ponomarev V. L. Filter cartridges: from simple to complex. Water and water treatment technologies. 2015. 1-2, 75-76. [In Russian].

Promyšlennaâ čistota. Fil'try i fil'truûsie èlementy. Metody ispytanij. [GOST R 50554-93].

Road vehicles. Test dust for filter evaluation. Arizona test dust. [British standard. BS ISO 121031:1997].

Sikorska E. Ph. D. Thesis. Warsaw, 2017.

Sikorska E., Gac J. M., Gradon L. Performance of a depth fibrous filter at particulate loading conditions. Description of temporary and local phenomena with structure development. Chemical Engineering Research and Design. 2018. 132, 743-750.

SUEZ Water Technologies \& Solutions. www.suezwatertechnologies.com. 2019.

Water conditioning equipment inside buildings. Mechanical filters. Particle rating. [British standard. BS EN 13443-2:2005+A1:2007]. 